\title{
Public Investments in Croatia
}

Ott, Katarina; Bajo, Anto

Source / Izvornik: Occasional Paper Series, 1999, 3, 1 - 27

Journal article, Published version

Rad u časopisu, Objavljena verzija rada (izdavačev PDF)

https://doi.org/10.3326/ops.7

Permanent link / Trajna poveznica: https://urn.nsk.hr/urn:nbn:hr:242:658678

Rights / Prava: Attribution-NonCommercial-NoDerivatives 4.0 International/ImenovanjeNekomercijalno-Bez prerada 4.0 međunarodna

Download date / Datum preuzimanja: 2023-04-26

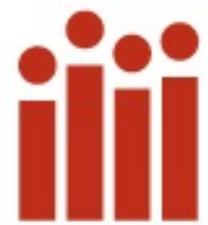

Repository / Repozitorij:

Institute of Public Finance Repository

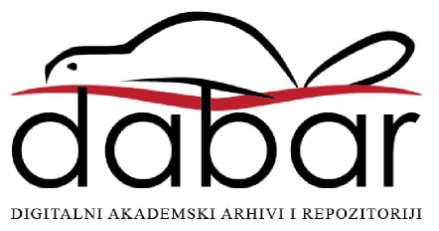




\section{PUBLIC INVESTMENTS IN CROATIA}

Katarina Ott \& Anto Bajo

Occasional Paper No. 7

March 1999

\footnotetext{
Institute of Public Finance

Katančićeva 5, 10000 Zagreb

CROATIA

tel: +38514819363

fax: +38514819365

ured@ijf.hr

(C) Institute of Public Finance 1999
} 


\title{
PUBLIC INVESTMENTS IN CROATIA
}

\author{
Katarina Ott \& Anto Bajo
}

This Occasional Paper occurred as the byproduct of preparations for writing the report by Geoff Dixon, Katarina Ott and Jean-Jacques Dethier "Capital Expenditure by the Government in Croatia: Fiscal Accounts, Budgetary Institutions and Budgeting Process”, The World Bank, Europe and Central Asia Region, Poverty Reduction and Economic Management Unit, June 1998.

The authors, Katarina Ott and Anto Bajo (Institute of Public Finance) first published the text in Croatian in the Institute's journal "Financijska praksa" Volume 23, Number 1, (March 1999). This Occasional Paper is the English language translation of the article published in "Financijska praksa". 


ABSTRACT
$\begin{aligned} & \text { The purpose of this paper is to analyze public investment or capital expenditures in the Republic } \\ & \text { of Croatia. The paper begins with an overview of public sector statistics regarding capital } \\ & \text { investment financing. One of the most difficult tasks was to adapt the idiosyncratic reporting } \\ & \text { method of Croatian public sector statistics to more usual public expenditure conventions. } \\ & \text { After an attempt at statistical systematization in line with conventional procedures, and analysis } \\ & \text { of the results obtained, the paper tries to point to the problems that arise during the preparation } \\ & \text { and execution of the budget. These problems are connected with existing participants in the } \\ & \text { budget process: local governments, public enterprises, extra-budgetary funds, government } \\ & \text { agencies, the payments clearing agency, the government auditing agency, and the (non)existent } \\ & \text { government treasury. } \\ & \text { The paper offers some suggestions for improvements in the capital investment financing process. } \\ & \text { These relate to the improvement of public sector statistics; the establishment of the government } \\ & \text { treasury; the reevaluation of the roles of the payments clearing agency, the other government } \\ & \text { agencies and the public enterprises; problems of local government financing, of the allocation of } \\ & \text { funds through the Croatian Bank for Reconstruction and Development, of development vs. } \\ & \text { reconstruction financing, of government auditing, of government guarantees, and of the necessity } \\ & \text { of foreign sources of financing. The paper especially emphasizes the fact that no cost benefit } \\ & \text { analysis and no transparent bidding for and evaluation of budget project procedures are involved. } \\ & \text { Further research should contribute to the solution of the problems identified. }\end{aligned}$




\section{PUBLIC INVESTMENTS IN CROATIA}

\section{Introduction}

The purpose of this paper is to present detailed accounts on capital (as opposed to current) spending by the government in Croatia since 1994 Because of major classification and reporting problems in Croatian government financial statistics, the figures presented here, both in nominal terms and as shares of GDP, are preliminary.

Data Sources. The data presented in the tables are taken from two main sources. The first source is constituted by reports on the execution of the budgets for 1994, 1995, 1996 and 1997. These reports were produced by the Department for Budget Preparation/Consolidation and the Department for Budget Execution of the Ministry of Finance (MOF). The second major source is represented by the annual reports for 1993-1997 and data for 1998 of the Croatian Bank for Reconstruction and Development (CBRD). The information on the capital budget is from the MOF (capital budget was introduced from 1996).

Classification. The expenditure data in this paper are generally not presented according to the GFS functional classification but according to sectors of government. MOF publishes monthly statistical reports with official data in accordance with the GFS methodology for central government and extra-budgetary funds. Unfortunately, these data are not detailed enough. It is therefore difficult to capture the correct amount of transfers between the budget and the extrabudgetary funds and public enterprises that are not consolidated within general government.

Consolidation. No attempt was made in this paper to consolidate the three sets of official data for the central budget, the extra-budgetary funds and local governments. This implies that when capital expenditures are calculated for each level of government, capital transfers to other levels of the government are not netted out. It also means that we have not attempted to trace the flow of funds from the central government to extra-budgetary funds, except for aggregate amounts (published by the MOF). Finally, this also entails local government accounts not having been consolidated with central government accounts. In Table 2, the data are "consolidated" by deducting from central budget accounts the amounts of capital transfers to extra-budgetary funds and by increasing extra-budgetary fund accounts by the same amount for those transfers. In Table 2, all items of extra-budgetary funds are divided into two parts: own sources and capital transfers from the central government. In Table 3, the same data are then divided into sectors of destination.

Shares of Gross Domestic Product. GDP estimates used in this paper for 1994, 1995 and 1996 are those published by the Statistical Office and, for 1997 and 1998 (projected), those of the MOF Monthly Statistical Bulletin No.29. These MOF estimates rely primarily on data from the Croatian National Bank.

\section{Capital Budget}

\footnotetext{
${ }^{1}$ K. Ott and A. Bajo thank Geoff Dixon and Jean-Jacques Dethier for all they have learned during the collaboration. They also thank Ed Feige, Ilona Castro and Tine Stanovnik for useful remarks and suggestions.
} 
Aggregate data on capital expenditure by the central government, extra-budgetary funds and local governments are presented in Table 1. These data are preliminary. Capital expenditure of the central government in this table include capital transfers from the central government to the extrabudgetary funds and local governments.

From these data it can be concluded that the major share of capital investment is financed at central government level, and that funds from the central government budget have a leading role in capital project financing. The share of central capital spending in total government expenditure grew from $5.70 \%$ in 1994 to $9.78 \%$ in 1997. In the 1998 budget, a decrease of capital expenditures is projected (to $9.56 \%$ of total budget expenditures). Capital expenditure by extra-budgetary funds as a share of total government expenditure averaged $1 \%$ in the period 1994-1997.

Capital expenditure by local governments increased during the period 1995-1997. However, this must be viewed with caution since data for 1994 and budget execution data for 1997 and 1998 for local governments are not available. These numbers refer to capital investments financed from own sources by local governments. Capital investments of local governments as a part of GDP grew from $1.9 \%$ in 1995 to $2.8 \%$ in 1996 and $3.7 \%$ in 1997.

In Table 1, the capital expenditure of extra-budgetary funds is shown for each major fund. The data indicate that the share of extra-budgetary funds in the total capital expenditure is very small, with the biggest share (0.75\%) going to the Croatian Road Fund. Since 1995 the Croatian Road Fund has been directly financed from the central budget. The share of capital spending by the Croatian Water Fund in total expenditures grew from $0.26 \%$ in 1994 to an estimated 1\% in the 1998 budget. Capital spending by the Health Insurance Fund (HIF) increased from $0.13 \%$ in 1995 ; $0.34 \%$ in 1996 and $0.48 \%$ in 1997 . The 1998 budget estimate indicates a smaller capital expenditure for the HIF $(0.40 \%)$.

Tables 2-3 present budget information on investment spending by central budgetary institutions and by the five extra-budgetary funds (the Pension, Health, Employment, Child Benefit and Road funds). Investment by state-owned enterprises - whether they are for-profit or not-for-profit would only be accounted for in Tables 2-3 to the extent that they received transfers from the central government for investment purposes. However, the budgets for 1994-1998 do not contain information on capital transfers to enterprises (with the exception of Croatian Railways). The budgets contain some information on current transfers from the central government to enterprises but they are not included in these tables. Loans from CBRD are not included in Tables 2-3. Capital transfers from the central budget to extra-budgetary funds are included in Tables 2-3.

Table 4. For central government and extra-budgetary funds, the information in Table 4 is identical to that in Table 2. Table 4 also presents data on capital spending at local government level. However investments financed by foreign sources are not included. Local government data for 1995 and 1996 are actuals; for 1997, budget estimates. According to this table, the share of local

\footnotetext{
${ }^{2}$ A note of caution is in order regarding the data in Table 1 . The table indicates that total nominal government expenditures in 1997 are lower than in 1996, which in reality is not the case. The 1997 and 1998 general government expenditure data in this table will have to be revised when we receive better information. Moreover, the data for 1998 is not comparable to previous years' data since local government budgets for 1998 are not included. It should also be noted that total "public investment" (by central government and extra-budgetary funds) in Table 3 is not equal to total public expenditures for those same institutions in table 1, which is indicative of significant data problems.
} 
government in financing capital projects in total general government level was around $22 \%$ in $1995,23 \%$ in 1996 and $28 \%$ in 1997 . Around $95 \%$ of funds came from local government's own sources of revenues. There is no systematic information on the participation of foreign sources in financing capital projects at local government level, and it is therefore close to impossible to estimate it. It is not possible to present a sectoral breakdown of capital spending at local government level either. Generally speaking, there is no coordination in unification and systematization of data between individual local governments and regional financial departments.

Table 5 presents information from the capital expenditure section of the central government budget for which foreign sources could be identified. It was not possible to present systematic information on capital expenditure financed through CBRD and the Ministry of Development and Reconstruction. Available data indicate that foreign funds are mostly from IBRD and EBRD. Part of the funds went to reconstruction of health and utility infrastructure, and the majority went to the building and reconstruction of roads.

Table 6 presents data on "acquisition of capital assets" and "capital transfers" by the central government. Construction of capital premises accounts for a substantial part of central government capital investment. This item (which is given a more analytical presentation in Table 7) accounts for around $30 \%$ of total capital expenditures. Investment in building capital premises in government ownership (mainly public administration buildings and border crossings) has also been significant, accounting for about $10 \%$ of the total in 1995, 40\% in 1996, 27\% in 1997 and 19\% (planned) in 1998.

Tables 7-8 present a breakdown of the item "construction of capital facilities" from the previous table for 1996-98, by type of ministry (or other public institution) and by sector. The majority of funds (over 63\%) was spent by the Ministry of Maritime Affairs, Transportation and Communication on road construction. A substantial part of the funds (around 17\%) was channeled through CBRD. In 1997 and 1998, a significant portion went to the Ministry of Reconstruction and Development, partly financed through CBRD and partly directly to beneficiaries. It is unfortunately not possible to give detailed presentation of investments by the Ministry of Reconstruction and Development.

Tables 9-13 present data on lending by the Croatian Bank for Reconstruction and Development (CBRD) taken from the annual financial reports of CBRD. Table 9 gives a sectoral breakdown of loans made by the CBRD in 1993-1997. In 1993-1995 the majority of funds (90\%) went to the water, building and electricity industry sectors. In 1996-1997 substantial amounts also went to tourism and the hotel/catering industry (around 35\% in 1996 and 20\% 1997). The data classification for 1997 includes a new item ("government sector") which accounts for over 7\% of total lending. It is not clear what is recorded under this item.

Table 10 presents lending by CBRD according to type of beneficiary. In 1993 the majority of funds (over 93\%) went to households for the reconstruction of war-damaged houses and apartments, or for new construction. In 1994-1995 around 90\% of funds went to state-owned companies. In 1996-1997 lending was split evenly between private and state-owned companies.

\section{General Commentary on the Data}

Until 1996, the Ministry of Reconstruction and

Development (MORD) developed an Annual 
Program of Economic Reconstruction combining investment proposals from various central government ministries and local government authorities. The budget contained special accounts for the financing of reconstruction projects. These accounts were subject to regulations prescribing the criteria and conditions for use of the funds.

Over the period 1994 to 1997, capital expenditure by the government was primarily driven by the reconstruction of war-damaged infrastructure, particularly housing, roads, water treatment plants and health care facilities. However, the data in Table 3 indicate a growing emphasis on "development-focused" capital expenditures. Public investment on "reconstruction" peaked at $33 \%$ of total public investment in 1996 falling to about $20 \%$ of the total in the 1988 budget. It should be remembered that the projects are listed under "reconstruction" or other categories by the ministries themselves, so that it is not possible to obtain an accurate breakdown between reconstruction expenditures and development expenditures.

After 1996, procedures for capital financing by agencies of the government changed. Agencies seeking funding from the budget for capital projects now have to submit their proposals directly to the MOF rather than to the MORD. In the MOF, the proposals are then entered into the unified budget preparation database.

In 1994, the largest public investment category was 'public administration facilities' (building, equipment and maintenance of government facilities and border crossings). In 1995-97, public investment in 'reconstruction' was the largest category. However, in the 1998 budget, 'public administration facilities' becomes once again the single largest category ( $21 \%$ of total) of public investment. The third largest category of public investment is roads which, however, declines from a peak of almost 19\% in 1996 to $14 \%$ in the 1998 budget estimates. This is followed by investment in water supply at about $11 \%$ of public investment and by housing for disabled soldiers.

The data in Tables 1-8 exclude investment projects financed by the Croatian Bank for Reconstruction and Development (CBRD). In some respects, lending undertaken by CBRD is an extension of budgetary funding of capital projects. CBRD is partly funded by annual cash injections from the budget and a major component of its lending activity is at the government's behest and does not reflect independent investment decisions by this financial institution. More than $90 \%$ of CBRD lending in its first three years (1993-95) went to reconstruction programs (mostly water works, apartments, etc). CBRD subsequently began undertaking mandatory lending on behalf of the Government (around 10\% of its lending during 1995 and over 50\% during 1996) and CBRD lending went mainly to state-owned and state-managed companies, especially in the water, construction and electricity sectors. In 1996, 35\% of CBRD funds went to tourism ventures. Since 1996, CBRD lending to private companies has increased greatly.

Local governments (at the provincial and municipal levels) have also borrowed funds for capital purposes. However the fiscal capacity of most regional government units is low and most of the funding for their capital activities comes from the central government, either through the ministry responsible for the particular project or through the CBRD. Consolidated data for capital spending at the local level are not available.

\footnotetext{
${ }^{3}$ Investment in power generation is excluded from the data because HEP is treated in this accounting framework as a profit-making enterprise. 


\section{Budgetary Problems}

\section{Local governments}

Local governments finance their investments in capital projects with funds from the central government budget. They have no financial potential for bigger investment ventures, nor are their revenues big enough for serious financing. In accordance with the law that regulates local unit financing, local units can open special accounts for financing capital projects. But, in accordance with the Budget Law, these expenditures can be financed only through local government unit budgets. Consequently, the central government budget allocates funds for financing local capital projects through relevant ministries. Funds for financing capital projects are distributed to particular ministries. Ministries distribute these funds for local projects, usually according to some key factor, and usually according to priorities. Funds can be granted through CBRD and through commercial banks. Financial reports of CBRD show that in the period 1992-1995 almost 60\% of funds were directed towards war damaged territories, mostly for reconstruction purposes.

The fiscal capacity of the majority of local governments (all except 3 or 4 ) is below the average. This is why capital projects are supposed to be financed at local level from central level (MOF) and through relevant ministries. Local governments have no capital budgets. Capital items at a local level are part of current budgets. There is some local level initiative for financing capital projects also.

Local governments are theoretically able to raise domestic or foreign loans but they are limited by difficulties in obtaining guarantees from the MOF. Short-term indebtedness is possible for financing regular activities and beneficiaries of their budgets if budget revenues are not collected at appropriate intervals during the year. Long-term indebtedness is possible for investment in fixed assets and for the improvement of the work of the local governments. Local governments can also issue bonds. Decisions can be made by local governments. They must in that case submit a detailed financial plan and seek approval from the MOF. They can also conclude foreign credit arrangements for financing reconstruction and development programs and projects with the consent of the Croatian Government. They can take on foreign credits up to $10 \%$ of budget expenditures executed in the previous year and with the consent of the MOF. They must have previous guarantees for the regular fulfillment of credit obligations, and overall annual foreign obligations may not amount to more than $30 \%$ of budget expenditures in the previous year.

The budget deficits of local governments may be financed by taking loans from other local governments, from the central budget or by loans from the non-banking sector including households. Indebtedness is allowed only for the financing of capital expenditures. The main obstacle for more local borrowing activities is the level of available funds of local governments. On the one hand, there are local governments that cannot finance their current expenditures without direct transfers (grants) from the central budget. Project grants, for capital expenditures do not exist, neither do criteria for their approval. On the other hand, there are economically more viable local governments, which attempt to finance capital projects independently. We could mention the examples of the Istarska zupanija and the town of Opatija (and the intentions of the Varazdinska zupanija and the Kastela municipalities) that issue bonds for financing capital projects for building and improvements of hospitals, collecting liquid waste, etc. However, local initiative is strongly restricted by available funds. 


\section{Public enterprises and the extra budgetary funds}

Croatian public finance statistics include: the central government budget; and the budgets of regional governments (zupanije); local governments (municipalities and towns), and extrabudgetary funds. The latter consist of: the Pension and Disability Insurance, Health Insurance, Employment, and Child Benefit funds, and the public enterprise Croatian Water. Various other public enterprises exist in Croatia too, but they are not considered extra-budgetary funds and they are not consolidated within the budget. The central government consolidated budget includes all the funds mentioned. Croatian Water has been consolidated since 1994 and Croatian Roads was consolidated only for 1994. One of the problems connected with the extra-budgetary funds is the underdeveloped system of statistics. Computerization is not yet as developed as necessary and data on revenues and expenditures flow in too slowly.

Extra-budgetary funds draw up financial plans. They use the classification system of budget accounting and follow the budgetary procedures proscribed by the MOF. Proposals of the financial plans of extra-budgetary funds must be delivered to the MOF who may make suggestions, changes and amendments. Financial plans must be approved by the Parliament on the proposal of the Government and recommendation of the MOF, simultaneously with the approval of the government budget.

Extra-budgetary funds' revenues from contributions and fees are usually not satisfactory and the majority of these funds regularly register a deficit. These deficits are usually covered from the government budget. Lack of funding is a main reason that there is no active investment policy. In accordance with reconstruction priorities, capital projects of extra-budgetary funds are also financed from the government budget. Funds for capital projects are disbursed directly from the MOF to public enterprises through CBRD. Extra-budgetary funds are usually not involved in large investment projects. Extra-budgetary funds can take long-term loans from the government budget and from the non-banking sector with the previous consent of the MOF. Decisions concerning public debt and government guarantees can be made at the suggestion of the Government by the Parliament.

\section{Agencies}

Croatia has three newly established (as yet not particularly funded) agencies that merit attention. Of lesser importance are the Agency for Public Investment and the Agency for Promoting Investment. More important is Croatian Guarantee Agency (CGA) whose goal is the improvement and development of small and medium sized enterprises and small trades. Its basic activity consists of issuing guarantees for loans granted to small entrepreneurs by banks and savings institutions and giving financial subventions for reducing the costs of loans made to small entrepreneurs by banks and savings institutions. Looking at the laws and decrees that established these agencies, (particularly the CGA), it would be helpful if their position within the budget were clarified. Their assets are a part of the budget (equipment is financed through the budget), but there is less clarity concerning their obligations. It ought to be much more obvious who it is that is balancing their budgets and controlling the items in them. From the available data it is not easy to say whether the government has paid its share in the CGA or not. Neither can it be said with any certainty whether CGA guarantees are listed as government obligations in the list of overall obligations and whether they are added 
foreign part of that debt. Further investigation would be required before these questions can be answered.

\section{The problem of guarantees}

The government can give guarantees for financing capital projects and loan guarantees (financial and indemnity). When it comes to financial guarantees, the total amount for 1998 is limited to $1,000,000,000.00$ kunas. Besides that amount, the government can on behalf of the Republic of Croatia give financial guarantees to CBRD for loans not exceeding a total of $750,000,000.00$ kunas. Half of this amount is required to be used for development projects of privately owned small and medium sized enterprises and trades. The MOF is obliged to take $6 \%$ of the guaranteed amount from the government budget and put it in a guarantee reserve (in a special account with the National Bank). But, if we speak about government indemnity guarantees, there is no obligation to set aside some percentage or amount in the guarantee reserve, nor are there any annual limits. This could well lead to a very dangerous situation.

CBRD can give guarantees to shipyards for collection of their liabilities, i.e. CBRD can get a counter-guarantee from the central government budget. A counter-guarantee is made by the Government.

The RC guarantees obligations incurred by CBRD with respect to securities issued and credits taken.

When it comes to repayment of loans by physical persons, in cases when the beneficiary has no means to insure the credit, a guarantee can be issued by the CGA.

\section{The Payments Clearing Agency}

The Payments Clearing Agency (PCA) is a public institution that keeps the accounts for the central government, local governments, enterprises and households. The data base of the MOF is supplemented with data collected by PCA which serves to establish the dynamic inflow of budgetary funds. PCA has prescribed accounts for payments of public revenues, the way in which these revenues are paid and reported to beneficiaries. PCA gives the Tax Administration Office (TAO), which is a part of the MOF, data on revenues collected for government, regional and city/municipal budgets. Revenues from PCA accounts are distributed in legally prescribed percentages to budgetary and extra-budgetary beneficiaries. The key for the distribution of shared revenues is defined by the TAO. The PCA charges a fee for its services connected with collecting payments in accordance with the agreement made between the PCA and the MOF.

\section{The Government Treasury}

The MOF organizational structure provides for the Government Treasury. It is supposed to be an organizational unit of the MOF responsible for the planning, execution and control of the government budget, fund management and government accountancy. In 1995 the Government aimed to draw up a program of gradual implementation of the system of the main Government 
Treasury book and a Government Treasury unified account. The final day for the beginning of the functioning of the Government Treasury was January 1, 1997. It was then that the Minister of Finance was entitled gradually to close the accounts of ministries and other governmental bodies opened with PCA. In accordance with the proposal of the MOF, the Government was supposed to define the schedule for the transition of beneficiaries on direct disbursements from the unified Treasury account. Unfortunately, the Government Treasury and the unified account of the Government Treasury are not functioning yet. Even efforts to connect them in one unified information net have slowed. Parallel with the concept of creation of a unified Treasury account, a move exists to establish a similar treasury and statistical recordings at the PCA. The PCA took over the function of the Government Treasury and unified accounts connected with the government budget. The PCA already functions as a government treasury and all payments and control of payments which are unified in the main book of the government budget are done through the PCA. It is quite contrary to intentions to integrate activities done by the PCA in the MOF, to take over the data base from the PCA, and to leave PCA as just a payments clearing agency.

\section{The State Auditing Office}

The State Auditing Office (SAO) audits government expenditures, financial reports and the financial transactions of government sector units, local governments, legal persons partially or completely financed from the budget, legal persons with a majority government ownership and the National Bank. Government expenditures in that context include all current and capital expenditures financed from the government budget or relevant funds at the national level, and from the budget at the local government authority level. We question whether the SAO has fulfilled its main goal. Is it really possible to make an overall audit of enterprises with a government majority holding or an audit of transactions between budget fund beneficiaries, especially as far as capital expenditures are concerned, without including those funds in the consolidated central government budget? It is quite probable that even now, in spite of the existence of the SAO, the PCA could still give a better and more complete picture of the spending of budgetary funds. Recall that that the PCA actually functions as a government treasury.

\section{Recommendations}

\section{Improvements of the statistics of the public sector}

In order to improve the statistics of the public sector it is necessary to:

(a) Provide a functional classification of extra-budgetary funds including the Privatization Fund,

(b) Improve local government statistics, which should be collected by the MOF instead of the PCA. They should include records of transfers and subventions given by local governments themselves and be consolidated with the budgets of all governments.

(c) Include public enterprises with a government majority holding as well as government owned agencies and banks (i.e. CBRD) in the regular budget. The failure to make the transactions among them fully transparent creates great opportunities for various irregularities and the 
"dissipation" of funds.

(d) Harmonize and unify data collection concerning the preparation and execution of the budget from various sources like ministries, agencies, extra-budgetary funds, local governments and the PCA. Not even the data inside the MOF are sufficiently transparent (We recommend that the government adopts the GFS accounting conventions).

(e) Improve the system of statistics and particularly the computerization of the extra-budgetary funds so that the data can be produced in a timely manner.

(f) It would be desirable for the MOF to publish more consistent data with more disaggregation and greater analysis. In this way a more precise insight into public expenditures could be arrived at.

(g) To be able to evaluate the real level of public investment in Croatia, it would be necessary to consolidate the funds and transactions of CBRD derived from credit arrangements within central government.

\section{Establishment of Government Treasury}

It seems that the flow of funds, especially on the expenditure side, is dissipated in several ways. It is necessary to ensure efficient control of flow of funds on both the revenue and the expenditure side of the accounts. An organizational unit responsible for planning and executing government budget, control of government budget, fund management and government accountancy should be situated within the MOF. This means the establishment of the Government Treasury with a unified treasury book and a unified account that will enable direct disbursements. It also means the integration of activities done by PCA in the MOF, taking over the data base from PCA, and leaving the PCA just a payments clearing agency. This could be the way to establish more transparent and less expensive control of the government treasury and evaluation of the public sector's financial activities.

\section{A reexamination of the role of the Payments Clearing Agency}

The role of PCA should be reexamined. In a situation in which the MOF contracts jobs with the PCA, questionable issues could be raised, regarding the fees that the PCA charges for its services, the disposition of public funds while within the accounts of PCA, the much higher salaries in the PCA than in other parts of the public sector, the possible misuse of public sector data, etc. In some future research works it would be interesting to reexamine the annual reports of the PCA and make some conclusions about its position in the Croatian public sector. 


\section{Local government financing}

The few cases of public investments at the local government level demonstrate that there are possibilities for the local financing of investment projects in Croatia. Detailed analysis of the realistic circumstances of local governments, their needs and their abilities to finance capital projects from their own sources should be undertaken. Local governments should keep separate capital and current budget accounts. Two separate budget accounts would allow a more transparent overview of capital investment funds. It could probably at the same time be a more economical approach as there would be fewer administrative procedures through ministries.

\section{Distribution of funds through the Croatian Bank for Reconstruction and Development}

Capital projects funds are obtained from the central government budget and from international financial institutions. The central government budget has a separate section for financing capital expenditures. It elaborates in detail the amounts that should be distributed to various beneficiaries. Since 1995 the majority of funds for financing capital projects have been distributed through CBRD. It would be interesting to find out whether this will be a regular practice or whether it was just a short-term decision and to see if this is the best possible practice. It would be useful to clarify the role of the Ministry of Reconstruction and Development and its relationship with the CBRD and to explain the ways in which funds are distributed and the criteria for the allotment of funds to particular beneficiaries. It would imply a serious cost-benefit analysis and the evaluation of investments.

\section{Reconstruction vs. development financing}

As a consequence of the war most capital project financing was allocated to reconstruction and less to development projects (since 1996, in tourism and small and medium size enterprises). Most capital project financing went to public enterprises (water, roads and electricity) but the distinction between reconstruction and development is not always easy to make. Probably, future efforts should be directed towards establishing clear distinctions and deciding upon the appropriate distribution of funds between reconstruction and development. Another issue to be considered in that context is the big share of nonproductive investments in public administration buildings and equipment (averaging around $20 \%$ of total public investment) that crowds out badly needed more productive investments.

\section{State Auditing Office}

Budget expenditures and expenditure control seem to be weak points. Although the Auditing Office has great competencies it seems not to use them sufficiently to carry out the overall audit of public enterprises, local governments and other institutions with majority government holdings. More detailed analysis of auditing procedures are needed for the future. In addition to the establishment of a Government Treasury, the way and the control of the spending of budget funds is certainly a priority. It is unrealistic to expect the Auditing Office to perform efficient and high quality audits without establishing a single account for all revenues and expenditures. The high tax burden in the country could probably be seen as an indicator of the irrational spending of 
government funds. Further research into the tax burden and its possible connection with government spending might help too. Greater control of revenue collection has already given results. The same activities on the expenditure side would be another step in the right direction.

\section{Role of agencies}

It would be necessary to clarify the position of the Croatian Guarantee Agency (CGA) and other agencies within the public sector. It seems that their assets are part of the budget (equipment purchases are financed through the budget), but situation with respect to their obligations is not as clear. It should be more obvious who balances and who controls their items in the budget. Data should be made available for questions like whether the government paid its share in the CGA or not, whether CGA guarantees are listed as government obligations in the list of total obligations and whether they are added to the public debt, and if so to the domestic or the foreign debt can be answered. Answers to these questions can only be provided after additional investigation.

\section{Foreign sources of financing}

The low level of public investment, particularly in comparison with the great needs (poor roads and other means of transportation), leads to the conclusion that there should be a reexamination of a larger role for foreign sources of financing. Great reliance on revenues from tourism seems unrealistic without quick and substantial improvements in transportation. As results in this domain cannot be quickly, it is important to take immediate steps in that direction.

\section{The status of public enterprises}

Although there are many public enterprises just two of them (Croatian Roads and Croatian Waters) are consolidated in the government budget. It is necessary to define the criteria for establishing the status of all public enterprises and the nature of their connections with the budget.

\section{General recommendation}

In short, we find that it is necessary to (a) improve coordination in the overall system of capital financing (reexamine spending in the relevant ministries), (b) accentuate development projects and restrain funds directed to public administration buildings and equipment, (c) make an overall analysis of public spending, (d) unify the program of public investment and harmonize the evaluation of investment projects.

\section{Further research}

Further research should include (1) the improvement of the financial statistics; (2) the improvement of capital budgeting processes (investigation of the public investment management cycle and testing the quality of budget institutions and processes), and (3) analyses of special issues as accentuated in the recommendations made above. 


\section{REFERENCES}

Auerbach, A. J. - Feldstein, M. (eds.) (1987) Handbook of Public Economics. Amsterdam: North-Holland.

Baker, S. H. - Elliot, C. S. (eds.) (1990) Readings in Public Sector Economics. Lexington: D.C. Heath and Company.

Brinkley, A. (1993) Liberals and Public Investment, Recovering a Lost Legacy. The American Prospect No. 13.

Campos, E. - Pradhan, S. (1996) Budgetary Institutions and Expenditure Outcomes. Washington: World Bank Policy Research Working Paper No. 1646.

Carbajo, J. - Frie, S. (1997) Restructuring Infrastructure in Transition Economies. European Bank for Reconstruction and Development Working Paper No. 2 (May 1997).

Cleland, D. I. - King, W. R. (1998) Project Management Handbook. New York: Van Nostrand Reinhold.

Corry, D. (ed.) (1997) Public Expenditure, Effective Management and Control. London: The Dryden Press.

Diamond, J. (ed.) (1994) Budget System Reform in Economies in Transition - The Case of the Former Soviet Union. Washington: IMF, Fiscal Affairs Department.

Dur, R.A.J. et all. (1998) The Effect of Fiscal Rules on Public Investment if Budget Deficits are Politically Motivated. Rotterdam: Erasmus University.

Ferlie, E. - Ashburner, L. - Fitzgerald, L. - Pettigrew, A. (1996) The New Public Management in Action. Oxford: Oxford University Press.

Holmes, M. (1998) The Public Expenditure Management Handbook. Washington: World Bank, Public Sector Management Unit.

International Monetary Fund (1996) Government Finance Statistics Manual. Washington.

International Monetary Fund (1997) Government Finance Statistics Yearbook. Washington.

Jackson, P. - Terry, F. (1990) Public Domain 1990, A Yearbook for the Public Services. London: Public Finance Foundation.

Lynch, T. D. (1995) Public Budgeting in America. London: Prentice-Hall Int.

McKevitt, D. - Lawton, A. (eds.) (1994) Public Sector Management, Theory, Critique and Practice. London: SAGE Publications.

OECD (1993) Pay Flexibility in the Public Sector. Paris.

OECD (1997) The Changing Role of the Central Budget.

Pradhan, S. (1996) Evaluating Public Spending - A Framework for Public Expenditure Reviews. Washington: World Bank Discussion Paper No. 323.

Reed, B. J. - Swain, J. W. (1997) Public Finance Administration. London: SAGE Publications.

World Bank (1997) Croatia Beyond Stabilization. Washington: World Bank Report No. 17261-HR. 
Table 1: General Government: Total and Capital Expenditure, 1994-98

in Croatian kunas

\begin{tabular}{|c|c|c|c|c|c|c|c|c|c|c|}
\hline & 1994 & $\%$ & 1995 & $\%$ & 1996 & $\%$ & 1997 & $\%$ & 1998 & $\%$ \\
\hline Total general government expenditure & 38.597.985.000 & 100,00 & 48.139.844.000 & 100,00 & 54.784.640.000 & 100,00 & 53.345.263.000 & 100,00 & 58.263.492.000 & 100,00 \\
\hline Total central government expenditure & 23.017 .705 .000 & & 28.696.187.570 & & 34.104 .088 .000 & & 38.196 .970 .000 & & 39.134 .563 .634 & \\
\hline Capital expenditure and capital transfers of the $\mathbf{C G}$ & 2.198 .296 .000 & 5,70 & 3.205 .819 .000 & 6,66 & 5.318 .000 .000 & 9,71 & 5.218.151.091 & 9,78 & 5.567 .411 .000 & 9,56 \\
\hline Capital expenditure of extra-budgetary funds & 389.293.000 & 1,01 & 344.635.000 & $\mathbf{0 , 7 2}$ & $\mathbf{5 3 7 . 4 8 8 . 3 9 0}$ & 0,98 & 691.572.852 & 1,30 & 741.154.000 & 1,27 \\
\hline Pension Fund & 0 & 0,00 & 16.059 .000 & 0,03 & 14.297 .390 & 0,03 & 15.507 .852 & 0,03 & 26.149 .000 & 0,04 \\
\hline Health insurance Fund & 0 & 0,00 & 64.262 .000 & 0,13 & 187.389 .000 & 0,34 & 257.518 .000 & 0,48 & 231.258 .000 & 0,40 \\
\hline Employment Fund & 0 & 0,00 & 0 & 0,00 & 29.787 .000 & 0,05 & 15.424 .000 & 0,03 & 27.896 .000 & 0,05 \\
\hline Public Water Management Fund & 101.477 .000 & 0,26 & 264.314 .000 & 0,55 & 306.015 .000 & 0,56 & 402.853 .000 & 0,76 & 582.000 .000 & 1,00 \\
\hline Croatian Public Roads & 287.816 .000 & 0,75 & & & & & & & & \\
\hline Capital expenditure of local governments* & N/A & & 920.942.348 & 1,91 & 1.539 .640 .389 & 2,81 & 1.975 .861 .683 & 3,70 & N/A & \\
\hline
\end{tabular}

* Local government data for 1997 are budget data only. Data for 1994 and 1998 are not available.

Source: Ministry of Finance, Central Government Budget, Extra-budgetary Funds and Local Government Budgets, 1995-1997 
Table 2: Public Investment in Croatia, Central Government and Extra-budgetary Funds, 1994-1998

in Croatian kunas

\begin{tabular}{|c|c|c|c|c|c|c|c|c|c|c|}
\hline & 1994 & $\%$ & 1995 & $\%$ & 1996 & $\%$ & 1997 & $\%$ & budget 1998 & $\%$ \\
\hline Central government budget & 1.731.034.000 & 66,90 & 2.887.276.000 & 83,19 & 4.911.813.000 & 86,08 & 4.670.676.000 & 82,60 & 5.317.267.000 & 84,29 \\
\hline 1. Construction/Reconstruction of housing for war veterans & 454.700 .000 & 17,57 & 1.287.082.000 & 37,08 & 2.406 .138 .000 & 42,17 & 1.842 .052 .000 & 32,57 & 1.937 .865 .000 & 30,72 \\
\hline 2. Key projects (transport and island development) & 155.092 .000 & 5,99 & 693.115 .000 & 19,97 & 1.130 .567 .000 & 19,81 & 783.592 .000 & 13,86 & 748.790 .000 & 11,87 \\
\hline $\begin{array}{l}\text { 3. Reconstruction of infrastructure (education, culture, } \\
\text { environment) }\end{array}$ & 265.940 .000 & 10,28 & 187.160 .000 & 5,39 & 233.495 .000 & 4,09 & 474.858.000 & $\mathbf{8 , 4 0}$ & 814.677.000 & 12,91 \\
\hline 4. Development projects (Industry and Agriculture) & 191.100 .000 & 7,39 & 0 & 0,00 & 271.480 .000 & 4,76 & 437.813 .000 & 7,74 & 205.600 .000 & 3,26 \\
\hline 5. Ministries' own projects* & 664.202 .000 & 25,67 & 672.901 .000 & 19,39 & 870.133 .000 & 15,25 & 924.444 .000 & 16,35 & 1.351 .140 .000 & 21,42 \\
\hline Extra-budgetary Funds & 856.555 .000 & 33,10 & 583.602 .000 & 16,81 & 794.098.390 & 13,92 & 984.153.852 & 17,40 & 991.298.000 & 15,71 \\
\hline Pension Fund & $\mathbf{0}$ & 0,00 & 16.059 .000 & 0,46 & 14.297.390 & 0,25 & 15.507.852 & 0,27 & 26.149.000 & 0,41 \\
\hline Own resources & & 0,00 & 16.059 .000 & 0,46 & 14.297 .390 & 0,25 & 15.507 .852 & 0,27 & 26.149 .000 & 0,41 \\
\hline Capital transfers from CG & 0 & 0,00 & 0 & 0,00 & 0 & 0,00 & 0 & 0,00 & 0 & 0,00 \\
\hline Health Insurance Fund & $\mathbf{0}$ & 0,00 & 64.262 .000 & 1,85 & 187.389 .000 & 3,28 & 257.518.000 & 4,55 & 231.258.000 & 3,67 \\
\hline Own resources & 0 & 0,00 & 64.262 .000 & 1,85 & 187.389 .000 & 3,28 & 257.518 .000 & 4,55 & 231.258 .000 & 3,67 \\
\hline Capital transfers from CG & 0 & 0,00 & 0 & 0,00 & 0 & 0,00 & 0 & 0,00 & 0 & 0,00 \\
\hline Employment Fund & $\mathbf{0}$ & 0,00 & $\mathbf{0}$ & 0,00 & 29.787.000 & 0,52 & 15.424 .000 & 0,27 & 27.896.000 & 0,44 \\
\hline Own resources & 0 & 0,00 & 0 & 0,00 & 29.787 .000 & 0,52 & 15.424 .000 & 0,27 & 27.896 .000 & 0,44 \\
\hline Capital transfers from CG & 0 & 0,00 & 0 & 0,00 & 0 & 0,00 & 0 & 0,00 & 0 & 0,00 \\
\hline Public Water Management Fund & 294.139.000 & 11,37 & 503.281.000 & 14,50 & 562.625 .000 & $\mathbf{9 , 8 6}$ & 695.704 .000 & 12,30 & 705.995.000 & 11,19 \\
\hline Own resources & 101.477 .000 & 3,92 & 264.314 .000 & 7,62 & 306.015 .000 & 5,36 & 402.853 .000 & 7,12 & 582.000 .000 & 9,23 \\
\hline Capital transfers from CG & 192.662 .000 & 7,45 & 238.967 .000 & 6,88 & 256.610 .000 & 4,50 & 292.851 .000 & 5,18 & 123.995 .000 & 1,97 \\
\hline Croatian Public Roads & 562.416 .000 & 21,74 & & & & & & & & \\
\hline Own resources & 287.816 .000 & 11,12 & & & & & & & & \\
\hline Capital transfers from CG & 274.600 .000 & 10,61 & & & & & & & & \\
\hline Total & 2.587.589.000 & 100,00 & 3.470.878.000 & 100,00 & 5.705.911.390 & 100,00 & 5.654.829.852 & 100,00 & 6.308.565.000 & 100,00 \\
\hline GDP & 85.299 .000 .000 & & 94.564 .000 .000 & & 103.610 .000 .000 & & 113.288 .000 .000 & & 125.500 .000 .000 & \\
\hline Total as percent of GDP & 3,03 & & 3,67 & & 5,51 & & 4,99 & & 5,03 & \\
\hline
\end{tabular}

Source: Ministry of Finance, Central Government Budget and Extra-budgetary Funds, 1994-1998 
Table 3: Public Investment by Sector, 1994-1998

in Croatian kunas

\begin{tabular}{|c|c|c|c|c|c|c|c|c|c|c|}
\hline & 1994 & $\%$ & 1995 & $\%$ & 1996 & $\%$ & 1997 & $\%$ & budget 1998 & $\%$ \\
\hline 1. Public Administration & 664.202 .000 & 25,19 & 672.901 .000 & 19,39 & 870.133 .000 & 15,25 & 924.444 .000 & 16,35 & 1.351 .140 .000 & 21,42 \\
\hline 2. Science and Education & 191.640 .000 & 7,27 & 138.786 .000 & 4,00 & 177.935 .000 & 3,12 & 243.277 .000 & 4,30 & 355.922 .000 & 5,64 \\
\hline 3. Reconstruction & 454.700 .000 & 17,25 & 772.780 .000 & 22,26 & 1.897 .978 .000 & 33,26 & 1.464 .791 .000 & 25,90 & 1.237 .865 .000 & 19,62 \\
\hline \multicolumn{11}{|l|}{ 4. Transport } \\
\hline - Road & 562.416 .000 & 21,33 & 482.449 .000 & 13,90 & 1.060 .567 .000 & 18,59 & 926.509 .000 & 16,38 & 868.725 .000 & 13,77 \\
\hline - Maritime & 128.000 .000 & 4,86 & 202.904 .000 & 5,85 & 35.000 .000 & 0,61 & 0 & 0,00 & 43.260 .000 & 0,69 \\
\hline - Other & 12.020 .000 & 0,46 & 7.762 .000 & 0,22 & 0 & 0,00 & 0 & 0,00 & 96.000 .000 & 1,52 \\
\hline 5. Welfare & 18.000 .000 & 0,68 & 16.059 .000 & 0,46 & 44.084 .390 & 0,77 & 30.931 .852 & 0,55 & 54.045 .000 & 0,86 \\
\hline 6. Culture and Protection of Historical Monuments & 9.300 .000 & 0,35 & 31.500 .000 & 0,91 & 53.060 .000 & 0,93 & 175.000 .000 & 3,09 & 163.000 .000 & 2,58 \\
\hline 7. Health & 30.798 .000 & 1,17 & 64.262 .000 & 1,85 & 187.389 .000 & 3,28 & 257.518 .000 & 4,55 & 231.258 .000 & 3,67 \\
\hline 8. Water & 294.139 .000 & 11,16 & 503.281 .000 & 14,50 & 562.625 .000 & 9,86 & 695.704 .000 & 12,30 & 705.995 .000 & 11,19 \\
\hline 9. Agriculture and Industry & 191.100 .000 & 7,25 & 0 & 0,00 & 271.480 .000 & 4,76 & 437.813 .000 & 7,74 & 205.600 .000 & 3,26 \\
\hline 10. Environment & 0 & 0,00 & 2.250 .000 & 0,06 & 2.500 .000 & 0,04 & 10.000 .000 & 0,18 & 60.000 .000 & 0,95 \\
\hline 11. Housing for Disabled Veterans & 0 & 0,00 & 514.302 .000 & 14,82 & 508.160 .000 & 8,91 & 377.261 .000 & 6,67 & 600.000 .000 & 9,51 \\
\hline 12. Public Services & 65.000 .000 & 2,47 & 14.624 .000 & 0,42 & 0 & 0,00 & 46.581 .000 & 0,82 & 85.755 .000 & 1,36 \\
\hline 13. Other & 15.072 .000 & 0,57 & 47.018 .000 & 1,35 & 35.000 .000 & 0,61 & 65.000 .000 & 1,15 & 250.000 .000 & 3,96 \\
\hline Total & 2.636.387.000 & 100,00 & 3.470.878.000 & 100,00 & 5.705.911.390 & 100,00 & 5.654 .829 .852 & 100,00 & 6.308 .565 .000 & 100,00 \\
\hline GDP & 85.299 .000 .000 & & 94.564 .000 .000 & & 103.610 .000 .000 & & 113.288 .000 .000 & & 125.500 .000 .000 & \\
\hline Total as percent of GDP & 3,09 & & 3,67 & & 5,51 & & 4,99 & & 5,03 & \\
\hline
\end{tabular}

Source: Ministry of Finance, Central Government Budget and Extra-budgetary Funds, 1994-1998

\section{Notes on Table 3.}

Public administration includes investments for buildings, maintenance and equipment for public administration (including border crossings).

Science and education includes investments in building, maintenance and equipment for schools, universities, research \& science institutions

Reconstruction is a separate item in the budget. No detailed breakdown is provided. Mostly funds for financing reconstruction needs through the Ministry of Reconstruction and Development.

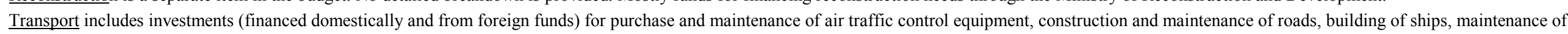
maritime premises, and projects by Croatian Railways.

Welfare includes construction of buildings and equipment for the social security funds.

Culture and the protection of the historical heritage includes the reconstruction and maintenance of the cultural heritage (Dubrovnik, Osijek, Ston, etc.), preservation of churches, etc.

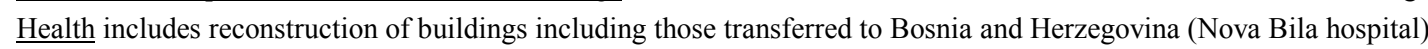

Water includes capital transfers from central budget and own funds of Croatian Water (Hrvatske Vode) 
Agriculture and industry includes subsidies and grants to industry and agriculture, and purchases of government commodity reserves

Environment includes funding for the protection of the environment (especially protection of Kastela bay)

Housing for Disabled Veterans includes funds for construction and purchase of apartments and houses for disabled war veterans.

Public services includes construction of communal public utilities (such as water, fire-brigades, local infrastructure) and some funds for building houses and apartments (the latter being a questionable item)

Other includes all national development projects such as island development projects, and other funds not classified under other line items. 


\section{Table 4: Public Investment in Croatia, by Central Government, Extra-budgetary Funds and Local Governments, 1994-1998}

in Croatian kunas

\begin{tabular}{|c|c|c|c|c|c|c|c|c|c|c|}
\hline & 1994 & $\%$ & 1995 & $\%$ & 1996 & $\%$ & 1997 & $\%$ & budget 1998 & $\%$ \\
\hline I Central Government & 1.731.034.000 & 66,90 & 2.887.276.000 & 64,57 & 4.911.813.000 & 66,42 & 4.670.676.000 & 59,23 & 5.317.267.000 & 84,29 \\
\hline 1. Construction/Reconstr. of housing for veterans & 454.700 .000 & 17,57 & 1.287 .082 .000 & 28,78 & 2.406 .138 .000 & 32,54 & 1.842 .052 .000 & 23,36 & 1.937 .865 .000 & 30,72 \\
\hline 2. Key projects (transport and island development) & 155.092 .000 & 5,99 & 661.644 .000 & 14,80 & 886.592 .000 & 11,99 & 783.592 .000 & 9,94 & 748.790 .000 & 11,87 \\
\hline 3. Infrastructure reconstr.(education, culture, environment) & 265.940 .000 & 10,28 & 186.489 .000 & 4,17 & 233.495 .000 & 3,16 & 474.858 .000 & 6,02 & 814.677 .000 & 12,91 \\
\hline 4. Agriculture and Industry & 191.100 .000 & 7,39 & 0 & 0,00 & 271.480 .000 & 3,67 & 437.813 .000 & 5,55 & 205.600 .000 & 3,26 \\
\hline 5. Own projects of ministries & 644.202 .000 & 24,90 & 607.819 .000 & 13,59 & 870.133 .000 & 11,77 & 924.444 .000 & 11,72 & 1.351 .140 .000 & 21,42 \\
\hline Financed by World Bank (IBRD) sources & 0 & 0,00 & 30.537 .000 & 0,88 & 172.988 .000 & 3,03 & 207.325.000 & 3,67 & 309.950 .000 & 4,91 \\
\hline Financed by other external sources & 20.000 .000 & 0,77 & 66.687 .000 & 1,92 & 71.987 .000 & 1,26 & 58.173 .000 & 1,03 & 276.667 .000 & 4,39 \\
\hline II Extra-budgetary Funds & 856.555 .000 & 33,10 & 583.602.000 & 13,05 & 794.098.390 & 10,74 & 984.153.852 & 12,48 & 991.298.000 & 15,71 \\
\hline Pension Fund & $\mathbf{0}$ & 0,00 & 16.059 .000 & 0,36 & 14.297.390 & 0,19 & 15.507.852 & $\mathbf{0 , 2 0}$ & 26.149.000 & 0,41 \\
\hline Own resources & 0 & 0,00 & 16.059 .000 & 0,36 & 14.297 .390 & 0,19 & 15.507 .852 & 0,20 & 26.149 .000 & 0,41 \\
\hline Capital transfers from C.G & 0 & 0,00 & 0 & 0,00 & 0 & 0,00 & 0 & 0,00 & 0 & 0,00 \\
\hline Health Insurance Fund & $\mathbf{0}$ & 0,00 & 64.262 .000 & 1,44 & 187.389 .000 & 2,53 & 257.518 .000 & 3,27 & 231.258.000 & 3,67 \\
\hline Own resources & 0 & 0,00 & 64.262 .000 & 1,44 & 187.389 .000 & 2,53 & 257.518 .000 & 3,27 & 231.258 .000 & 3,67 \\
\hline Capital transfers from C.G & 0 & 0,00 & 0 & 0,00 & 0 & 0,00 & 0 & 0,00 & 0 & 0,00 \\
\hline Employment Fund & $\mathbf{0}$ & 0,00 & $\mathbf{0}$ & 0,00 & 29.787.000 & 0,40 & 15.424.000 & $\mathbf{0 , 2 0}$ & 27.896.000 & 0,44 \\
\hline Own resources & 0 & 0,00 & 0 & 0,00 & 29.787 .000 & 0,40 & 15.424 .000 & 0,20 & 27.896 .000 & 0,44 \\
\hline Capital transfers from CG & 0 & 0,00 & 0 & 0,00 & 0 & 0,00 & 0 & 0,00 & 0 & 0,00 \\
\hline Public Water Management Fund & 294.139.000 & 11,37 & 503.281.000 & 11,26 & 562.625 .000 & 7,61 & 695.704 .000 & 8,82 & 705.995.000 & 11,19 \\
\hline Own resources & 101.477 .000 & 3,92 & 264.314 .000 & 5,91 & 306.015 .000 & 4,14 & 402.853 .000 & 5,11 & 582.000 .000 & 9,23 \\
\hline Capital transfers from CG & 192.662 .000 & 7,45 & 238.967 .000 & 5,34 & 256.610 .000 & 3,47 & 292.851 .000 & 3,71 & 123.995 .000 & 1,97 \\
\hline Croatian Public Roads & 562.416 .000 & 21,74 & & & & & & & & \\
\hline Own resources & 287.816 .000 & 11,12 & & & & & & & & \\
\hline Capital transfers from C.G & 274.600 .000 & 10,61 & & & & & & & & \\
\hline Total excluding local governments (I+II) & 2.587.589.000 & 100,00 & 3.470 .878 .000 & & 5.705 .911 .390 & & 5.654.829.852 & & 6.308.565.000 & 100,00 \\
\hline Total (I+II) as a percent of GDP & 3,03 & & 3,67 & & 5,51 & & 4,99 & & 5,03 & \\
\hline III Local governments * & & & & & & & & & & \\
\hline Capital expenditure & & & 1.000.518.649 & 22,38 & 1.689.218.207 & 22,84 & 2.230.755.774 & 28,29 & & \\
\hline of which: Capital transfers from CG & & & 14.162 .850 & 0,32 & 39.937.807 & 0,54 & 50.112 .000 & 0,64 & & \\
\hline Capital grants & & & 65.413 .451 & 1,46 & 109.640 .011 & 1,48 & 204.782 .091 & 2,60 & & \\
\hline Own funds of local government & & & 920.942 .348 & 20,60 & 1.539 .640 .389 & 20,82 & 1.975 .861 .683 & 25,06 & & \\
\hline Total including local governments (I+II+III) & & & 4.471.396.649 & & 7.395.129.597 & & 7.885.585.626 & & & \\
\hline Total $(\mathrm{I}+\mathrm{II}+\mathrm{III})$ as a percent of GDP & & & 4,73 & & 7,14 & & 6,96 & & & \\
\hline
\end{tabular}

Local government data for 1997 are budget, not actuals

Source: Ministry of Finance, Central Government Budget, Extra-budgetary Funds and Local Government Budgets, 1995-1997 
Table 5: Budget Information on Foreign-financed Investment (Central Government), 1994-98

in Croatian kunas

\begin{tabular}{|c|c|c|c|c|c|c|c|c|c|c|}
\hline & 1994 & $\%$ & 1995 & $\%$ & 1996 & $\%$ & 1997 & $\%$ & 1998 & $\%$ \\
\hline Acquisition of building for diplomatic \& consular representatives -HYPO Bank & 20.000 .000 & 100,00 & 65.082 .000 & 66,94 & & & & & & \\
\hline Equipment for flight control administration - IBRD Credit & & & 1.605 .000 & 1,65 & & & & & & \\
\hline Construction of roads- IBRD Credit & & & 29.866 .000 & 30,72 & 172.988 .00 & 70,61 & 160.744 .000 & 60,54 & 172.245 .000 & 29,36 \\
\hline Reconstruction of health facilities in primary health care - IBRD & & & 671.000 & 0,69 & & & & & & \\
\hline Construction of roads - EBRD Credit & & & & & 71.987 .000 & 29,39 & 48.173 .000 & 18,14 & 185.000 .000 & 31,54 \\
\hline Project of reconstruction of infrastructure - IBRD Credit & & & & & & & 46.581 .000 & 17,54 & 70.755 .000 & 12,06 \\
\hline Participation of Government in EBRD credit (rehabilitation of Kaštelanski bay) & & & & & & & 10.000 .000 & 3,77 & 50.000 .000 & 8,52 \\
\hline Part of the CEF loan for reconstruction of schools & & & & & & & & & 41.667 .000 & 7,10 \\
\hline Reconstruction of Eastern Slavonija - IBRD Credit & & & & & & & & & 65.000 .000 & 11,08 \\
\hline Construct. of roads-Emergency Reconstruction-IBRD Credit & & & & & & & & & 1.950 .000 & 0,33 \\
\hline Total & 20.000 .000 & 100,00 & 97.224 .000 & 100,00 & 244.975 .00 & 100,00 & 265.498 .000 & 100,00 & $\mathbf{5 8 6 . 6 1 7 . 0 0 0}$ & 100,00 \\
\hline
\end{tabular}

Source: Ministry of Finance, Central Government Budget, 1994-1998 
Table 6: Capital Expenditure and Capital Transfers, Central Government, 1994-1998*

in Croatian kunas

\begin{tabular}{|c|c|c|c|c|c|c|c|c|c|c|}
\hline & 1994 & $\%$ & 1995 & $\%$ & 1996 & $\%$ & 1997 & $\%$ & 1998 & $\%$ \\
\hline \multicolumn{11}{|l|}{$\begin{array}{l}\text { Total capital expenditure and capital transfers } \\
\text { I. Acquisition of fixed capital assets }\end{array}$} \\
\hline & & & 0 & 0,00 & 71.565 .355 & 1,42 & 70.210 .600 & 1,56 & 112.325 .000 & 2,04 \\
\hline Stated owned building & & & 333.216 .449 & 10,44 & 2.055.218.228 & 40,69 & 1.211 .232 .190 & 26,92 & 1.040 .933 .937 & 18,94 \\
\hline Acquisition of office furniture and equipment & & & 141.079.172 & 4,42 & 159.514 .336 & 3,16 & 186.553 .145 & 4,15 & 248.723 .126 & 4,53 \\
\hline Stated-owned vehicles & & & 22.833 .576 & 0,72 & 13.686 .169 & 0,27 & 10.396.607 & 0,23 & 17.360 .000 & 0,32 \\
\hline Equipment, plant & & & 0 & 0,00 & 22.588 .690 & 0,45 & 21.808 .940 & 0,48 & 31.000 .000 & 0,56 \\
\hline Other material property & & & 0 & 0,00 & 22.986 .188 & 0,46 & 44.568 .703 & 0,99 & 48.942 .100 & 0,89 \\
\hline Intangible assets in state property & & & 1.030 .000 & 0,03 & 122.649 .035 & 2,43 & 168.479 .859 & 3,74 & 171.132 .733 & 3,11 \\
\hline Purchases of stocks & & & 0 & 0,00 & 2.100 .300 & 0,04 & 1.449 .365 & 0,03 & 2.066 .000 & 0,04 \\
\hline Construction of capital facilities & & & 1.016.746.000 & 31,85 & 1.288.635.883 & 25,52 & 1.644.817.484 & 36,56 & 1.747 .056 .615 & 31,79 \\
\hline Investment maintenance & & & 33.386 .200 & 1,05 & 115.346 .481 & 2,28 & 137.885 .929 & 3,06 & 213.402 .003 & 3,88 \\
\hline Subtotal I: & 1.588.767.000 & 50,86 & 1.548.291.397 & 48,51 & 3.874.290.665 & 76,71 & 3.497.402.822 & $\mathbf{7 7 , 7 4}$ & 3.632.941.514 & 66,11 \\
\hline \multicolumn{11}{|l|}{ II. Capital transfers } \\
\hline to households and non-financial institutions & & & 514.320 .888 & 16,11 & 434.302 .000 & 8,60 & 241.824 .600 & 5,38 & 726.460 .000 & 13,22 \\
\hline to rest - of - the world (abroad) & & & 26.460 .561 & 0,83 & 14.800 .000 & 0,29 & 11.840 .000 & 0,26 & 15.000 .000 & 0,27 \\
\hline to state institutions & & & 27.726 .771 & 0,87 & 135.000 .000 & 2,67 & 148.000 .000 & 3,29 & 178.995 .000 & 3,26 \\
\hline to other level of national government & & & 0 & 0,00 & 0 & 0,00 & 0 & 0,00 & 50.000 .000 & 0,91 \\
\hline to financial and non-financial institutions & & & 78.631 .500 & 2,46 & 7.030 .000 & 0,14 & 7.030 .000 & 0,16 & 7.030 .000 & 0,13 \\
\hline Other capital transfers & & & 996.573 .561 & 31,22 & 584.974 .563 & 11,58 & 512.922 .316 & 11,40 & 803.750 .000 & 14,63 \\
\hline to the same level of government & & & 0 & 0,00 & 0 & 0,00 & 80.000 .000 & 1,78 & 81.000 .000 & 1,47 \\
\hline Subtotal II: & 1.535.000.000 & 49,14 & 1.643.713.281 & 51,49 & 1.176.106.563 & 23,29 & 1.001.616.916 & 22,26 & 1.862 .235 .000 & 33,89 \\
\hline $\begin{array}{l}\text { Total (I+II) capital expenditure and capital } \\
\text { transfers }\end{array}$ & & & 3.192.004.678 & 100,00 & 5.050.397.228 & 100,00 & 4.499.019.738 & 100,00 & 5.495 .176 .514 & 100,00 \\
\hline
\end{tabular}

* Table 6 presents data on acquisition of fixed capital assets and capital transfers by the central government. More details on new investments ("construction of capital facilities") for 1996-98 are given in Tables 7-8.

Source: Ministry of Finance, Central Government Budget, 1994-1998 
Table 7: New Investments, 1996-98 Classification by type of institution*

\begin{tabular}{|c|c|c|c|c|c|c|}
\hline & 1996 & $\%$ & 1997 & $\%$ & 1998 & $\%$ \\
\hline Croatian Government & 1.835 .000 & 0,14 & & & & \\
\hline Ministry of Finance & 81.382 .488 & 6,32 & 74.915 .608 & 4,55 & 65.750 .000 & 3,76 \\
\hline CBRD- Croatian Bank for Rec. and Develop. & 215.878.000 & 16,75 & & & & \\
\hline Ministry of Foreign Affairs & 3.500 .000 & 0,27 & 2.800 .000 & 0,17 & 3.200 .000 & 0,18 \\
\hline Ministry of Mar. Aff. , Transport and Communication & 819.743 .933 & 63,61 & 736.515 .163 & 44,78 & 525.930 .000 & 30,10 \\
\hline Flight control administration & 4.151 .933 & 0,32 & 18.923 .163 & 1,15 & 14.400 .000 & 0,82 \\
\hline Croatian Roads & 815.592 .000 & 63,29 & 717.592 .000 & 43,63 & 509.530 .000 & 29,17 \\
\hline Inland water transport administration & & & & & 2.000 .000 & 0,11 \\
\hline Ministry of Physical Planning, Building and Housing & 31.220 .762 & 2,42 & & & 4.100 .000 & 0,23 \\
\hline Ministry of Education and Sports & 63.149 .053 & 4,90 & 84.983 .463 & 5,17 & 142.520 .000 & 8,16 \\
\hline Ministry of Labor and Welfare & 16.134 .643 & 1,25 & 10.413 .908 & 0,63 & 31.420 .000 & 1,80 \\
\hline Ministry of Science and Technology & 53.903 .908 & 4,18 & 29.456 .519 & 1,79 & 10.700 .000 & 0,61 \\
\hline Ministry of Justice & 557.694 & 0,04 & 4.718 .744 & 0,29 & 23.540 .000 & 1,35 \\
\hline Constitutional Court of the Rep. of Croatia & 18.000 & 0,00 & & & & \\
\hline State Office for Protection Cultural and Natural Heritage & 1.312 .400 & 0,10 & & & & \\
\hline Ministry of Reconstruction and Development & & & 700.306 .275 & 42,58 & 810.000 .000 & 46,36 \\
\hline Ministry of Culture & & & & & 2.199 .615 & 0,13 \\
\hline Ministry of Economic Affairs & & & & & 900.000 & 0,05 \\
\hline Ministry of Health & & & & & 1.500 .000 & 0,09 \\
\hline Total & 1.288.635.881 & 100,00 & 1.644.817.481 & 100,00 & 1.747.056.615 & 100,00 \\
\hline
\end{tabular}

* Presents breakdown of "construction of capital facilities" (see Table 6) by type of institution, for 1996-98

Source: Ministry of Finance, Central Government Budget, 1996-1998 
Table 8. New Investments, 1996-98 Classification by sector

in Croatian kunas

\begin{tabular}{|c|c|c|c|c|c|c|}
\hline Construction & 1996 & & 1997 & & 1998 & \\
\hline Roads, railways and bridges & 815.592 .000 & 63,29 & 717.592 .000 & 43,63 & 509.530 .000 & 29,17 \\
\hline Air, maritime, rivers harbor & 1.991 .081 & 0,15 & 1.916 .428 & 0,12 & 124.029 .000 & 7,10 \\
\hline Border crossings, parks & 57.452 .438 & 4,46 & 55.743 .608 & 3,39 & 51.750 .000 & 2,96 \\
\hline Public Buildings & 79.192 .338 & 6,15 & 99.266 .116 & 6,04 & 202.098 .000 & 11,57 \\
\hline Buildings, machinery, equipment & 60.162 .225 & 4,67 & 610.516 .079 & 37,12 & 703.550 .000 & 40,27 \\
\hline Building operations & 35.883 .747 & 2,78 & 139.226 .432 & 8,46 & 150.800 .000 & 8,63 \\
\hline Other capital facilities & 238.362 .053 & 18,50 & 20.556 .819 & 1,25 & 5.299 .615 & 0,30 \\
\hline Total & 1.288 .635 .882 & 100,00 & 1.644 .817 .482 & 100,00 & 1.747.056.615 & 100,00 \\
\hline
\end{tabular}

Source: Ministry of Finance, Central Government Budget, 1996-1998. 
Table 9: Croatian Bank for Reconstruction and Development (CBRD), Lending by sector of activity, 1993-1997*

in 000 Croatian kunas

\begin{tabular}{|c|c|c|c|c|c|c|c|c|c|c|}
\hline & 1993 & $\%$ & 1994 & $\%$ & 1995 & $\%$ & 1996 & $\%$ & 1997 & $\%$ \\
\hline Waterworks & $64.120,00$ & 63,15 & $92.282,00$ & 60,75 & $199.660,00$ & 67,72 & $257.580,00$ & 39,67 & $329.963,00$ & 45,44 \\
\hline Construction & $9.532,00$ & 9,39 & $26.206,00$ & 17,25 & $25.308,00$ & 8,58 & $23.383,00$ & 3,60 & $5.460,00$ & 0,75 \\
\hline Electricity & $20.764,00$ & 20,45 & $22.580,00$ & 14,86 & $24.001,00$ & 8,14 & $21.336,00$ & 3,29 & $17.914,00$ & 2,47 \\
\hline Tourism and catering & 231,00 & 0,23 & 0,00 & 0,00 & 0,00 & 0,00 & $230.681,00$ & 35,53 & $143.909,00$ & 19,82 \\
\hline Textile and leather & 0,00 & 0,00 & 0,00 & 0,00 & $4.415,00$ & 1,50 & $36.342,00$ & 5,60 & $46.018,00$ & 6,34 \\
\hline Non-metal and metal industry & $1.270,00$ & 1,25 & $3.105,00$ & 2,04 & $3.007,00$ & 1,02 & $8.569,00$ & 1,32 & $14.989,00$ & 2,06 \\
\hline Rubber and plastics & 0,00 & 0,00 & 0,00 & 0,00 & 0,00 & 0,00 & $13.088,00$ & 2,02 & $22.250,00$ & 3,06 \\
\hline Food industry & $3.509,00$ & 3,46 & $3.089,00$ & 2,03 & $2.438,00$ & 0,83 & $6.049,00$ & 0,93 & $5.474,00$ & 0,75 \\
\hline Wood based and wood processing industry & 0,00 & 0,00 & 0,00 & 0,00 & 0,00 & 0,00 & $10.274,00$ & 1,58 & $24.877,00$ & 3,43 \\
\hline Trade and services & $1.650,00$ & 1,63 & 934,00 & 0,61 & 641,00 & 0,22 & $3.977,00$ & 0,61 & $3.081,00$ & 0,42 \\
\hline Mining & 0,00 & 0,00 & 0,00 & 0,00 & 0,00 & 0,00 & 96,00 & 0,01 & 95,00 & 0,01 \\
\hline Agriculture & 297,00 & 0,29 & 65,00 & 0,04 & 65,00 & 0,02 & $6.990,00$ & 1,08 & $5.857,00$ & 0,81 \\
\hline Publishing & 0,00 & 0,00 & 0,00 & 0,00 & 0,00 & 0,00 & $2.401,00$ & 0,37 & $4.524,00$ & 0,62 \\
\hline Citizens & 155,00 & 0,15 & 145,00 & 0,10 & 811,00 & 0,28 & $2.244,00$ & 0,35 & 0,00 & 0,00 \\
\hline Transport & 0,00 & 0,00 & 0,00 & 0,00 & 0,00 & 0,00 & $3.480,00$ & 0,54 & $13.345,00$ & 1,84 \\
\hline Oil industry & 0,00 & 0,00 & $3.510,00$ & 2,31 & $26.635,00$ & 9,03 & 0,00 & 0,00 & 0,00 & 0,00 \\
\hline Government sector & & & & & & & & & $53.038,00$ & 7,30 \\
\hline Machinery manufacturing & & & & & & & & & $9.919,00$ & 1,37 \\
\hline Others & 0,00 & 0,00 & 0,00 & 0,00 & $7.835,00$ & 2,66 & $22.832,00$ & 3,52 & $25.412,00$ & 3,50 \\
\hline Total & $101.528,00$ & 100,00 & $151.916,00$ & 100,00 & $294.816,00$ & 100,00 & $649.322,00$ & 100,00 & $726.125,00$ & 100,00 \\
\hline
\end{tabular}

* Lending data, net of loan loss provisions

Source: CBRD, Annual Reports (1993-1997) 
Table 10: Croatian Bank for Reconstruction and Development lending by type of beneficiary (1993-1997)

in 000 Croatian kunas

\begin{tabular}{|c|c|c|c|c|c|c|c|c|c|c|}
\hline & 1993 & $\%$ & 1994 & $\%$ & 1995 & $\%$ & 1996 & $\%$ & 1997 & $\%$ \\
\hline Private companies & 155 & 0,15 & 16.155 & 10,63 & 19.931 & 6,76 & 331.328 & 51,02 & 353.147 & 47,37 \\
\hline Stated-owned companies & 7.214 & 7,11 & 132.106 & 86,96 & 267.491 & 90,73 & 294.926 & 45,41 & 362.269 & 48,60 \\
\hline Citizens & 94.159 & 92,74 & 145 & 0,10 & 811 & 0,28 & 2.244 & 0,35 & 6.262 & 0,84 \\
\hline Others & 0 & 0,00 & 3.510 & 2,31 & 6.583 & 2,23 & 20.914 & 3,22 & & \\
\hline Government sector & & & & & & & & & 53.038 & 7,11 \\
\hline Total & 101.528 & 100,00 & 151.916 & 100,00 & 294.816 & 100,00 & 649.412 & 100,00 & $\mathbf{7 4 5 . 4 7 3}$ & 100,00 \\
\hline
\end{tabular}

Source: CBRD, Annual Reports, 1993-97.

Table 11. Financing of Capital Projects through Croatian Bank for Reconstruction and Development (1993-96)

\begin{tabular}{|c|c|c|c|c|c|c|c|c|}
\hline Funds granted by projects & $\begin{array}{l}1993 \\
\text { DEM } \\
\end{array}$ & & $\begin{array}{c}1994 \\
\text { DEM } \\
\end{array}$ & & $\begin{array}{l}1995 \\
\text { HRK } \\
\end{array}$ & & $\begin{array}{l}1996 \\
\text { HRK } \\
\end{array}$ & \\
\hline & granted & $\%$ & granted & $\%$ & granted & $\%$ & granted & $\%$ \\
\hline \multicolumn{9}{|l|}{ I. From CBRD own funds } \\
\hline 1 Reconstruction of apartments and buildings & $100,000,000$ & 42.13 & $1,000,000$ & 0.61 & $102,240,185$ & 21.80 & 0 & 0.00 \\
\hline 2. Reconstruction and development of big companies & $62,387,246$ & 26.28 & $62,799,295$ & 38.30 & 0 & 0.00 & 0 & 0.00 \\
\hline 3. Reconstruction of nationally important infrastructure & $35,048,834$ & 14.77 & $92,743,772$ & 56.56 & 0 & 0.00 & 0 & 0.00 \\
\hline 4. Reconstruction of infrastructure & 0 & & $1,800,000$ & 1.10 & $110,611,298$ & 23.58 & $69,319,000$ & 5.72 \\
\hline 5. Reconstruction of the economy & 0 & & 0 & 0.00 & $147,466,047$ & 31.44 & $173,883,000$ & 14.35 \\
\hline 6. Reconstruction of livestock & $9,915,900$ & 4.18 & $1,070,000$ & 0.65 & $9,201,364$ & 1.96 & 0 & 0.00 \\
\hline 7. Reconstruction of agriculture machinery & $10,000,000$ & 4.21 & 0 & 0.00 & $9,201,364$ & 1.96 & 0 & 0.00 \\
\hline 8. Incentives to entrepreneurs in liberated and undeveloped regions & 0 & 0.00 & 0 & 0.00 & $5,014,209$ & 1.07 & 0 & 0.00 \\
\hline 9. Development of small and medium sized enterprises & 0 & 0.00 & 0 & 0.00 & $34,646,459$ & 7.39 & $64,069,000$ & 5.29 \\
\hline 10. Returnees from Germany & $20,014,659$ & 8.43 & 0 & 0.00 & $4,474,803$ & 0.95 & $10,522,000$ & 0.87 \\
\hline 11. Development of tourist sector & 0 & 0.00 & 0 & 0.00 & & 0.00 & $276,117,000$ & 22.79 \\
\hline 12. Credit to building materials industry & 0 & 0.00 & $4,548,641$ & 2.77 & 0 & 0.00 & 0 & 0.00 \\
\hline II. Funds from "Island Link" & 0 & 0.00 & 0 & 0.00 & $2,340,717$ & 0.50 & 0 & 0.00 \\
\hline III. Mandatory business * & 0 & 0.00 & 0 & 0.00 & $43,858,641$ & 9.35 & $617,721,000$ & 50.98 \\
\hline
\end{tabular}


* CBRD manages substantial amounts in the name and on the behalf of Ministry of Finance. There funds are used mostly for reconstruction and development and are kept separately from other CBRD's funds. Source: CBRD, Annual Reports, 1993-1996.

Table 12. Regional Allocation of Credits (1992-1995)

in Croatian kunas

\begin{tabular}{|l|c|c|}
\hline Regions & Used & \% \\
\hline Krapinsko-zagorska & $1,482,464$ & 0.11 \\
\hline Sisačko-moslovačka & $67,714,135$ & 5.14 \\
\hline Karlovačka & $67,714,135$ & 5.14 \\
\hline Varaždinska & $1,097,254$ & 0.08 \\
\hline Koprivničko-križevačka & $1,251,349$ & 0.10 \\
\hline Bjelovarsko-bilogorska & $15,525,094$ & 1.18 \\
\hline Primorsko-goranska & $6,522,862$ & 0.50 \\
\hline Ličko-senjska & $63,596,239$ & 4.83 \\
\hline Virovitičko-podravska & $32,805,521$ & 2.49 \\
\hline Požeško-slavonska & $61,766,772$ & 4.69 \\
\hline Brodsko-posavska & $61,052,320$ & 4.64 \\
\hline Zadarsko-kninska & $149,923,170$ & 11.38 \\
\hline Osječko-baranjska & $274,967,626$ & 20.88 \\
\hline Sibenska & $74,042,918$ & 5.62 \\
\hline Vukovarsko-srijemska & $168,315,907$ & 12.78 \\
\hline Splitsko-dalmatinska & $62,452,264$ & 4.74 \\
\hline Istarska & $1,684,465$ & 0.13 \\
\hline Dubrovačko-neretvanska & $161,953,348$ & 12.30 \\
\hline Međimurska & $1,302,305$ & 0.10 \\
\hline City of Zagreb and Zagreb Region & $41,698,998$ & 3.17 \\
\hline Total & $\mathbf{1 , 3 1 6 , 8 6 9 , 1 4 6}$ & $\mathbf{1 0 0 . 0 0}$ \\
\hline Sor:HkBo, & & \\
\hline
\end{tabular}

